UDC 332.05

JEL 011

DOI 10.31375/2226-1915-2020-2-53-62

Viktoria Marhitich

PhD student

viktoria.marhitich@uzhnu.edu.ua

ORCID 0000-0002-9310-3089

Uzhhorod National University, Uzhhorod, Ukrainian

\title{
LOGICAL AND COMPONENT CONSTRUCTION OF ANALYSIS OF ORGANIZATIONAL AND ECONOMIC POTENTIAL OF REGIONAL DEVELOPMENT
}

\begin{abstract}
The development of an economic system is determined by its potential, the effectiveness of which depends on the assessment of its current state and the possibilities of forming competitive advantages in the future.

The purpose of this study is to substantiate the necessary and feasibility of analyzing the organizational and economic potential from the standpoint of logical sequence and consistency. To achieve the goal, the following tasks were accomplished:

1. The essence of the organizational and economic potential and its system components is shown.

2. Based on the identified main system components to build a logical chain and analysis sequence of the main compositional parts of the organizational and economic potential.

Analysis of the organizational and economic potential, as well as any other phenomenon, depends on the nature of the object of study, its structure and features of functioning. The organizational and economic potential of strategic development contains a wide range of system components, each of which carries a certain functional load and contributes to the formation of certain strategic competitive advantages.

The logic of analysis includes threestages: 1. Analysis of organizational and economic components of the potential of the regional economy contains, 2. Analysis of innovation activity in the region as a strategic factor in the development of the economic system and the formation of its competitiveness, 3. Strategic assessment of regional potential, aimed at determining the strategic position of the region.

Analysis of organizational and economic components of the potential of the regional economy contains A). Structural architecture of potential; B). Foreign economic activity as an indicator of competitiveness of the regional system; $C$ ). The level of labor productivity as result of efficient administration at the enterprises and the region. Each of the stages carries a certain semantic load. At the first stage, the structure and effectiveness of organizational and economic potential is examined. It let us to see the potential as a definite system with definite elements. At the second step, the innovative component of regional development is investigated - the current competitiveness is examined. And at the third stage, it is studied the position of the region regarding to strategic development opportunities.

Keywords: organizational and economic potential, strategic development, regional development, integrated analysis.
\end{abstract}

(C) Marhitich V., 2020 
УДК 332.05

\section{JEL O11}

DOI 10.31375/2226-1915-2020-2-53-62

В. Маргитич аспирант кафедры экономики и предпринимательства

Ужгородский начиональный университет, Ужггород, Украина

\section{ЛОГИКО-КОМПОНЕНТНОЕ УСТРОЙСТВО} АНАЛИЗА ОРГАНИЗАЦИОННОЭКОНОМИЧЕСКОГО ПОТЕНЦИАЛА РЕГИОНАЛЬНОГО РАЗВИТИЯ

Аннотация. Анализ организационноэкономического потенциала, как и любого другого явления, зависит от характера объекта исследования, его структуры и особенностей функционирования. Организационно-экономиче ский потенииал стратегического развития содержит широкий спектр системных компонентов, каждый из которых несет определенную функциональную нагрузку и способствует формированию определенных стратегических конкурентных преимуществ.

Логика анализа включает в себя три вида:

1. Анализ организационно-экономических составляющих потенциала региональной экономики.

2. Анализ инновачионной активности в регионе как стратегического фактора развития экономической системь и формирования ее. конкурентоспособности.

3. Стратегическая оченка регионального потенциала, направленная на определение стратегического положения региона.

Анализ организационно-экономической составляющей потенциала региональной экономики содержит A). Структурная архитекту ра потенциала; Б). Внешнеэкономическая деятельность; С). Уровень производительности труда. Каждый из этапов несет определенную смысловую нагрузку. На первом этапе исследуется структура и эффективность организаии онного и экономического потенциала, на втором - инновачионная составляющая регионального развития, на третьем - потенциал региона $и$ региона по отношению к возможностям стратегического развития.

Ключевые слова: организационно-экономический потенциал, стратегическое развитие, региональное развитие, компоненты анали$3 a$.
УДК 332.05

JEL 011

DOI 10.31375/2226-1915-2020-2-53-62

\section{В. Маргітич аспірант кафедри економіки і підприємництва Ужггородський національний університет, Ужгород, Україна \\ ЛОГІЧНО-КОМПОНЕНТНА ПОБУДОВА АНАЛІЗУ ОРГАНІЗАЦІЙНО- ЕКОНОМІЧНОГО ПОТЕНЦІАЛУ РЕГІО- НАЛЬНОГО РОЗВИТКУ}

Анотація. Аналіз організаційно-економічного потенціалу, як $i$ будь-якого іншого явища, залежить від характеру об'єкта дослідження, його структури та особливостей функиіонування. Організачійно-еконо-мічний потенціал стратегічного розвитку містить широкий спектр системних компо-нентів, кожен з яких несе певне функиіо-нальне навантаження та сприяс формуванню певних стратегічних конкурентних переваг.

Логіка аналізу включає три етапи:

1. Аналіз організаційно-економічних компонентів потенціалу регіональної економіки.

2. Аналіз інновачійної діяльності в регіоні як стратегічного чинника розвитку економічної системи та формування ї̈ конкурентоспроможності. 3. Стратегічна оцінка регіонального потенціалу спрямована на визначення стратегічної позииії регіону.

Аналіз організаційно-економічних складових потенціалу економіки регіону містить A). Структурна архітектура потенціалу; Б). Зовнішньоекономічна діяльність; B). Рiвень продуктивності прачі. Кожен із етапів несе певне смислове навантаження. На першому етапі досліджується структура та ефективність організаційно-економічного потенціалу, на другому досліджується інноваиійна складова регіонального розвитку, на третьому потенціал регіону та регіону розмішується відносно можливостей стратегічного розвитку.

Ключові слова: організачійно-економічний потенціал, стратегічний розвиток, регіональний розвиток, комплексний аналіз. 
Problem statement. The deepening of market relations exacerbates the competition between the regions, which in turn makes it appropriate to study the success factors of the territorial system in achieving the leadership. Among such factors of development of regional economy it is possible to allocate the potential which creates a basis of development and provides regional management with economic and organizational tools. At the same time, the practice of functioning of regional economic systems proves that the effectiveness of the use of development potential largely depends on information about its strength, explicit and latent opportunities, prospects. It is possible to obtain all data on the potential and its organizational and economic component only on the basis of analysis data, which performs the following functions:

a) informational; b) diagnostic; c) administrative.

Analysis of organizational and economic potential should provide complete and comprehensive information that forms the basis of the diagnostic function. Diagnosis, in turn, allows you to identify problems and opportunities for the development of organizational and economic potential. The results of the diagnosis form the basis of management decisions.

The effectiveness of the analysis largely depends on the methodological framework, which outlines the stages and methods of assessing the organizational and economic potential. All this determines the urgency of the problem.

Review of the last research and publications. There are some methodical directions of analysis which are determined by the methodological ap- proach to the consideration of the essence of the potential.

The first direction is strategic analysis. In the modern investigations the strategic analysis is proposed by the following reason: «Potential is the basis for the implementation of the strategy; and, depending on the combination of potential opportunities and the adopted strategy, regional development options are possible. They take place in many spheres, and in this paper the economic and organizational are suggested to investigate. Organizational and economic potential interacts with the regional development strategy, allows to highlight the following combinations: active strategy and active development potential of the forward region; active strategy and passive potential - development is ambitious, but organizational and economic are not justified; passive strategy and active potential - irrational development when the existing potential is not used properly (regional management does not match the capabilities and capabilities of the regional economy); passive strategy, passive potential if development happens, the region takes advantage of existing advantages, does not create new opportunities and prospects» [7]. The most common method is SWOT, showing internal and external interbeds for research [4] and other tools are very actively using $[9 ; 10]$. Despite the fact that strategic analysis shows possible prospects for the development of potential, it does not reveal the depth of the relationship between the constituent elements of the potential.

The second direction is the factor approach, within which the potential is outlined as a set of factors that lead to a certain state. Slovak researcher Hvizdová E. (Hvizdová E., 2014) considers the 
potential as a set of cultural factors, but the author is limited to the study of only regional tourist destinations [6]. Based on this, the potential is considered as a factor and analyzed from the standpoint of causal induction: what factors affect the potential and how the potential by its action determines a certain result. Factor analysis did not avoid the disadvantage that lies in the lack of a metho-dology for determining factors that directly affect the result of the economic system. Using correlation analysis allows you to assess the presence of influence (or absence) but does not allow you to build a line of determining factors.

The next direction of analysis is connected with definite spheres of activity $[2 ; 3 ; 5]$ or different functions [1].

This approach suffers from a limitation: each sphere, type of activity is not a self-isolated phenomenon, but actively interacts with the outside world. The influence of external conditions affects the results of actions of the potential.

Mentality as a resource and a tool for analyzing the development potential is proposed in the works of Ukrainian researchers who argue that «Выступая фактором экономики постмодерна, ментальность выполняет следующие экономические функции: 1. Стимулирующую. Ценности могут быть ориентированы на самосовершенствование и духовный мир или же на материальный. 2. Оценочная. Шкала успеха и достижений зависит от морально-нравственных и этических критериев, лежащих в основе экономических акций. 3. Интеграционная. Ментальность, ориентированная на развитие, интегрирует внутренние силы, намерения, креативный потенциал и практические действия, обеспечивая тем самым синергию 4. Стратегическая. «Европейская цивилизация более нацелена на самоутверждение, тогда как восточная - при всей её вариативности - на освоение», и т.п.); 5. Культурная. Принимая культуру экономического развития определяет форму и содержание поведения экономических игроков в экономике постмодерна» [8].

The purpose of this study is to substantiate the necessary and feasibility of analyzing the organizational and economic potential from the standpoint of logical sequence and consistency.

To achieve the goal, the following tasks were accomplished:

1. The essence of the organizational and economic potential and its system components is shown.

2. Based on the identified main system components to build a logical chain and analysis sequence of the main compositional parts of the organizational and economic potential.

The methodological basis consists of methods: monographic research, the results of which allowed to explore modern theoretical discourses on the strategic potential of development and its components, the method of scientific abstractions, which proposed a composition of analysis; the application of the method of causal induction helped to outline the stages of analysis.

The basic material of research. Organizational and economic potential as a starting point for strategic development requires constant updating, restructuring and strengthening, respectively, the requirements of a certain period, which necessitates monitoring and evaluation of its components and their use. 
The organizational and economic potential of strategic development contains a wide range of system components, each of which carries a certain functional load and contributes to the formation of certain strategic competitive advantages. Within the limits of the given research among basic components of organizational and economic potential of long-term development we allocate:

a) a component of the organizational architecture of regional business, which is characterized by the number of economic entities and their structural organization;

b) foreign economic activity of the regional business system, which characterizes the quality of products in the region and demand for it in foreign markets, which is an indicator of the competitiveness of regional business;

c) labor efficiency in the region;

d) innovative component of development potential.

The proposed logic is based on the principles of causal induction, which allows to identify the cause-effect chain, which, in turn, leads to increased operational efficiency and strategic effectiveness of the regional economic system.

The logic of quantitative analysis and qualitative characterization of organizational and economic potential of strategic development is presented in Fig. 1.

The analysis takes place in three stages, each of which has a specific task.

At the first stage, the quantitative parameters of the use of organizational and economic components of the potential of strategic development are assessed, the second - is devoted to the study of innovation activity and its prospects; the third stage contains the results of studying the strategic aspects of opportunities for regional economic deve-lopment.

Analysis A provides an opportunity to assess the dynamics of different organizational forms of economic entities, which allows to determine the dynamics and their impact on the regional economy.

The results of $\mathrm{B}$ analysis of foreign economic activity diagnose the quality of products produced by enterprises in the region.

The level of labor productivity shows the effectiveness of the organizational and economic potential of the region.

Outlined in Fig. 1 logic of analysis requires the use of modern, adequate to the level of research techniques and methods. It is the methodological basis that determines the effectiveness of the analysis, which contributes to the justification of certain areas of improvement of organizational and economic potential of strategic development.

Assessment of the degree of realization of organizational and economic potential of the region includes several areas, for example, the analysis of indicators of economic entities of the region, which include both individual entrepreneurs and statutory entities. Each group performs certain functions in the mobilization and implementation of regional organizational and economic potential.

First, entrepreneurs perform a more important function of increasing employment among the population of the region and reducing the burden of the unemployed on vacancies in enterprises.

Second, entrepreneurs form and realize the human development potential of the region. Entrepreneurs master the knowledge necessary for business: how 
to start a startup, how to make management and business decisions, how to form and implement marketing policies, how to keep records, how to work with staff, etc. Entrepreneurs are constantly learning in practice, which significantly improves the quality of human potential in the region.

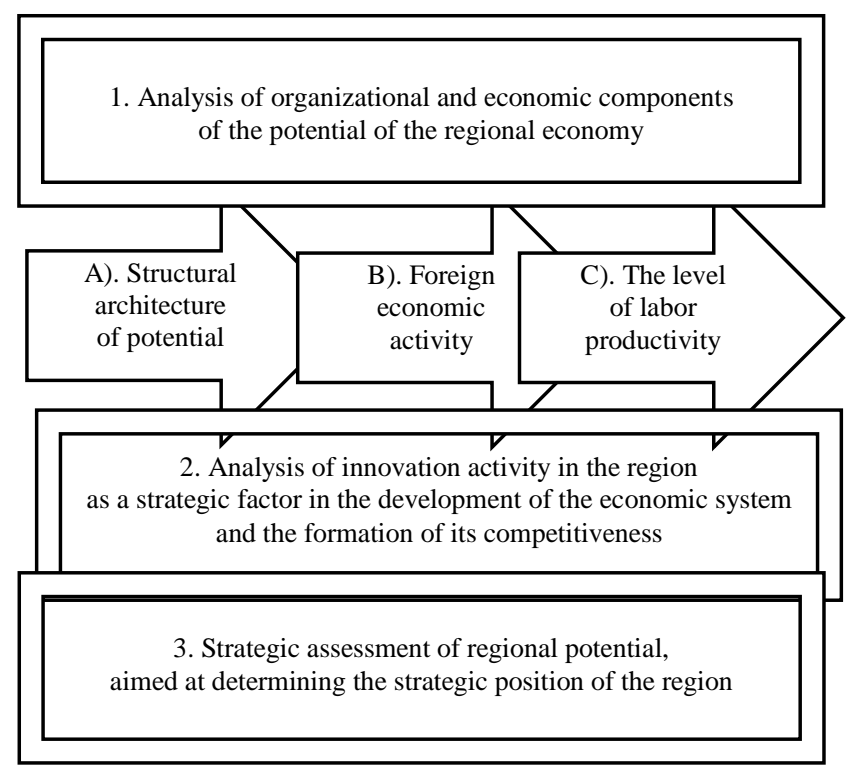

Fig. 1. Substantiation of the logic of the analysis of organizational and economic potential of strategic development of Zakarpattia region

Source: Own elaboration

Third, it is entrepreneurs who create a competitive environment by filling niches that are unfavorable for statutory entities.

Fourth, entrepreneurs by their nature are the driving force of the innovation process, implementing in practice the innovative direction of the idea and bringing them to commercial benefit.

Accordingly, enterprises play their own role in shaping the organizational potential of the region:

1. Due to the concentration of resources ensure the implementation of the principle of efficiency of economic potential. Concentration of resources pro- vides an opportunity for their multivariate combinatorics and maneuvering, which is an additional competitive advantage not only for business but also for the regional system as a whole.

2. Create the main array of jobs and thus form a regional labor market, determine the quantitative and qualitative parameters of labor potential, which will work effectively in terms of these organizational and economic opportunities.

3. The social function of enterprises is to form an internal microclimate, corporate culture and social environment, which contribute to the realiza- 
tion of organizational and economic potential of the region. It should be emphasized that many studies show that in large enterprises the level of wages is higher than in the sector of hired labor by entrepreneurs. This is due to the scale of the business, market share, and concentration of resources, as noted above.

All these arguments, the indicated value of business entities determines the need to study the structural state.

An analysis of foreign economic activity shows the level of competitiveness of products that are produced in the region.

The level of labor productivity indicates the effectiveness of living labor in the region, the level of organization of regional management, business and a separate workplace.

The second stage proposes to analyze the innovative component of the region's development potential, which will form loving competitive advantages in the future.

In continuation of the diagnosis, it is recommended to analyze the strategically possible scenarios for the development of the region.

Organizational and economic potential is a key condition for the strategic competitiveness of the region, which provides for the development of the economic system on the basis of development and implementation of innovations, strengthening human potential and cultural values that can become an institutional framework for future radical change.

This necessitates constant strategic analysis, which has two objectives:

first, diagnosis of strategic opportunities for regional development; secondly - the formation of strategic guidelines for the functioning of the region.

In other words, one of the important components of long-term administ-ration of regional development is strategic analysis, which allows to identify the position of the region in today's competitive world, outline ways of its deve-lopment and provide regional and national management information that allows relevant and adequate strategic decisions.

Extremely important in strategic analysis is the choice of methods that allow rational and efficient formation of the analytical base, determine diagnostic procedures and provide information for strategic decision making.

Recently, matrix tools of strategic analysis have been actively used. Matrix methods place high demands on the experts involved in the diagnosis, their theoretical training and practical experience.

The matrix method of strategic analysis is a combination of two sides, directions, forces, actions in a crossed form, which allows to create combinations of interaction of two different phenomena of economic life, which allow to position the region in four zones.

1. Zone 1 . The potential of the infantry. It is characterized by a low level of both organizational and economic potential of the regions. Requires large investments and government support;

2. Zone 2. The potential of the balloon. Organizational opportunities are quite high, but there is no economic basis for strategic development. A region with this type can start to develop very actively, but due to low economic potential there are great risks in the development process; 
Zone 3. The potential that falls in its diagnosis in the third segment acquires the essence of the train: the economy is the locomotive of the movement, but the effectiveness of economic actions is not effective due to lack of support for organizational resources;

Zone 4. High organizational potential and high economic potential create a zone of strategic opportunities to seize competitive advantages and implement modern methods and levers of strategic development of the region.

Matrix methods place high demands on the experts involved in the diagnosis, their theoretical training and practical experience.

Conclusion. Analysis of the organizational and economic potential, as well as any other phenomenon, depends on the nature of the object of study, its structure and features of functioning. The organizational and economic potential of strategic development contains a wide range of system components, each of which carries a certain functional load and contributes to the formation of certain strategic competitive advantages.
The logic of analysis includes three stages: 1. Analysis of organizational and economic components of the potential of the regional economy contains, 2. Analysis of innovation activity in the region as a strategic factor in the development of the economic system and the formation of its competitiveness, 3. Strategic assessment of regional potential, aimed at determining the strategic position of the region.

Analysis of organizational and economic components of the potential of the regional economy contains A). Structural architecture of potential; B). Foreign economic activity; C). The level of labor productivity. Each of the stages carries a certain semantic load. At the first stage, the structure and effectiveness of organizational and economic potential is examined, at the second, the innovative component of regional development is investigated, at the third, the potential of the region and the region are positioned relative to strategic development opportunities.

In a further study, it is planned to build a correlation model that will determine the defining factors.

\section{СПИСОК ЛІТЕРАТУРИ}

1. Дороніна О.А. Пріоритетні завдання кадрової політики щзодо удосконалення оцінки праиі та їі оплати // Вісник Хмельницького національного університету. 2010. № 6. C.173-178.

2. Мікловда В.П., Кубіній Н.Ю., Шандор Ф.Ф. та ін. Маркетинговий потенціал регіону: проблеми та шляхи їх подолання: монографія. Ужгород: Лipa, 2009. $208 \mathrm{c}$.

3. Холоденко А.М., Наврозова Ю.А. Оптимизачия уровня качества и цены круизного обслуживания // Розвиток методів управління та господарювання на транспорті: 3б. наук. пращь. Одеса: OHMУ, 2013. URL: http://www.osmu.odessa.ua/public/other/publishing/checkal32/3203.pdf (дата обращения: 19.10.2013). 
4. Наврозова Ю.О., Качюк В. СВОТ-аналіз передумов створення туристичного кластеру в Одеському регіоні // Розвиток методів управління та господарювання на транспорті: Зб. наук. пращь. Одеса: ОНМУ, 2016. № 4. C.57-72.

5. Наврозова Ю.А., Граждару Е.Д. Оченка влияния доходов потребителей на спрос на круизы в Средиземноморье // Розвиток методів управління та господарювання на транспорті: 3б. наук. праць. Одеса: ОНМУ. 2018. № 3. C.79-93. DOI https://doi.org/10.31375/2226-1915-2018-79-93

6. Hvizdová E. Culture - important factor for tourism development towards economic growth of the country // Central European Review of Economics \& Finance. 2014. № 3. Y.6. C.61-74.

7. Kubiniy N., Marhitich V., Kosovilka T. Modern Content of Strategic Regional Development Potential. Economics and Business. 2020. №1. URL: http:// eb.tsu.ge/?cat $=$ nomer\&leng $=$ eng \& adgi $=945 \&$ title $=$ Modern $\% 20$ Content $\% 20$ of\%20Strategic\%20Regional\%20Development\%20Potential

8. Kubiniy N. Mentality as a factor of economic development in the conditions of post-modern economy // Стратегія бізнесу: футурологічні виклики: 3б. матеріалів Міжнародної науково-практичної інтернет-конференції. К.: KHEУ, 2019. 495 c.

9. Papulova S., Gazova A. Role of Strategic Analysis in Strategic Deci- sion-Makin. URL: https://www.sciencedirect.com/ science/article/pii/ S221256711630301X

10. Utilizing the Various Strategic Analysis Tools. URL: https://www. visual-paradigm.com/guide/strategic-analysis/utilizing-the-various-strategicanalysis-tools

\section{REFERENCES}

1. Doronina, O. (2010) Priortetni zavdannya kadrovoi politiky shchodo udoskonalennya otsinky pratsitayiyi oplaty [Priority tasks of personnel policy to improve the evaluation of work and its payment]. Visnyk Khmel'nynskogo natsionalnogo universytetu - Bulletin of Khmelnytsky National University. № 6, 173-178 [in Ukrainian].

2. Miklovda, V.P. (2009) Marketynhovyi potentsial rehionu: problemy ta shliakhy yikh podolannia. [Marketing potential of the region: problems and ways to overcome them: monograph]. Uzhhorod: Lira, 208 [in Ukrainian].

3. Holodenko A. \& Navrozova Yu. (2013). Optimizatsia urovnya kachestva I tseny kruiznogo obsluzhyvania [Optimization of the quality and price of cruise services]. Rozvitok metodyv upravlinnya ta gospodaryuvannya na transporti Development of management and entrepreneurship methods on transport. Retrieved from: http://www.osmu.odessa.ua/public/other/ publishing/ checkal 32/3203.pdf [in Russian]. 
4. Navrozova Yu. \& Katsuk V. (2016) SWOT-analys peredumov stvorennya turystychnogo klasteru $v$ Odeskomu regioni [SWOT-analysis of changing minds nesting tourist cluster in Odessa region]. Rozvitok metodyv upravlinnya ta gospodaryuvannya na transporti - Development of management and entrepreneurship methods on transport. № 4, 57-72 [in Ukrainian].

5. Navrozova Yu. \& Grazhdaru, E. (2018). Otsenka vliyaniya dohodov potrebiteley na spros na kruizy $v$ sredizemnomor'i [Assessing the impact of consumer income on demand for cruises in the Mediterranean]. Rozvitok metodiv upravlinnya ta gospodaryuvannya na transporti - Development of management and entrepreneurship methods on transport. № 3, 79-93. DOI https:// doi.org/10.31375/2226-1915-2018-79-93 [in Russian].

6. Hvizdová E. (2014) Culture - important factor for tourism development towards economic growth of the country - Central European Review of Economics \& Finance. Vol.6, № 3, 61-74.

7. Kubiniy N., Marhitich V., Kosovilka T. (2020). Modern Content of Strategic Regional Development Potential. - Economics and Business. № 1. Retrieved from: http://eb.tsu.ge/?cat=nomer\&leng=eng \&adgi=945\&title=Modern $\% 20$ Content\%20of\%20Strategic\%20Regional\%20Development\%20Potential

8. Kubiniy N. (2019) Mentality as a factor of economic development in the conditions of post-modern economy - Styrategia biznesu: futurologichni vyklyky. K.: KNEU, 495.

9. Papulova S., Gazova A. Role of Strategic Analysis in Strategic DecisionMakin. Retrieved from: https://www.sciencedirect.com/ sciencelarticle/pii/ S221256711630301X

10. Utilizing the Various Strategic Analysis Tools. Retrieved from: https://www. visual-paradigm.com/guide/strategic-analysis/utilizing-the-various-strategicanalysis-tools

Article received 03.04.2020

Reference a JournalArtic: Marhitich Viktoria. (2020). Logical and component construction of analysis of organizational and economic potential of regional development. Development of management and entrepreneurship methods on transport. 2 (71), 53-62. DOI 10.31375/2226-19152020-2-53-62. 